（12）河本正彥等：精糖技研誌，No. 4, 1(1955); 兵庫農大研報，1，No. 2，63，66 (1954)； 同上, 4, No. 1, 43 (1959).

(13) S.M. Partridge : Nature, 164, 443(1949).

(14) R.H. Horrokes : ibid., 164; 444 (1949).

（15）佐竹一夫：クロマトグラフ，共立出版，p. 85 (1952).

(16) H.S. Isbe11 : U.S. Atomic Energy NBS5325, 39 (1957) ; C. A., 52, 15432 (1958).

(17) B. M. Ames et al.: J. Am. Chem. Soc,, 74, 252 (1952).

(18) V. Prey et al. : $Z$. für Zuckerind., 9 452 (1959).

（19）生化学の領域に拈ける光電比色法，各諭 1 , p. 105 (1958).
(20) L. Hough : J. Chem. Soc., 1958, 1212.

(21) J.F. O'Dea : Biochem. J., 55,580(1953).

（22）沒辺長男等：農産加工技研誌, 5, 137 (1958); 食研報，12，99（1957）。

（23）生化学領域に挌ける光電比色法, 各論 $2, \mathrm{p}, 36$ (1958)

(24) 同上, 各論 2 , p. 46 (1958).

(25) 同上, 各論 1, p. 67 (1958).

(26) J. C. Speck : Advances in Carbohydrate Chem., 13, 63 (1958).

(27) W. Pigman : "The Carbohydrates," Academic Press, 1957, p. 67.

(28) K. Bernhauer et a1. : Biochem. Z., 221, 11 (1930).

【费化 第 36 管, 第 4 号, p. $310 \sim 313,1962$ ]

$$
\begin{gathered}
\text { グルコースとアンモニアの反応生成物に } \\
\text { 関する化学的研觉 (第 } 2 \text { 報) } \\
\text { グルコシルアミン, グルコース及びアンモニアの分別定量法 }
\end{gathered}
$$

河 本 正 应 (兵嘎農科大学)

昭和 36 年 7 月 31 日受理

グルコースーアンモニア反応水溶液（以下 G-A 反怤液とする）中にグルコシルアミンが生成することを前報(1) に記した，この反応溶液中のグルコシルアミン，グルコース及びアンモニアの消長を検討するためには，三者の 分別定量法を確立する必要がある。しかし反応溶液中で直接三者を定量することは，ヴルコース及びグルコシル アミンが共汇還元力を有するため困難である，グルニースが中性物質であるのに対し，グルコシルアミンは塩基


考えられた。

従来一キソサミン（タルコサミン及びガラクトサミン）の定量に関し，陽イオン交換樹脂を用いる Boas(2) の方法があるので，著者はこの方法を準用してまずグルコース伎びグルコシルアミンの分別を行い，ついでそれ それれアンスロン法(3)により定量した．Boas の方法によれば，吸着されたへキッサミンをDowex 50 から溶出 後, Elson-Morgan 法により定量を行っている，乙かし著者の問題としている交換樹脂からの溶出液はグルコシ ルアミン以外化，もともと存在していたアンモニアと溶出に用いた塩酸とが反応して生じた塩化アンモンを含む ために，溶出液中のグルコシルアミンを Elson-Morgan 法(4)で定量するとき（十）の誤差を与えることがわか った．よって本実験に抬いては溶出液中のグルコシルアミンはアンスロン法により定量した.アンモニアは,グル コシルアミンと共に一旦交換樹脂に吸着せしめた後, 塩酸により塩化アンモンとして溶出し,インドフェノール 法 ${ }^{(5)}$ Kより定量した。

種々椮討の結果, Boas 法に準じた分離操作を行っだ後, 上記の各比色法を応用すると，グルコース，グルコ シルアミン及びアンモニアの分別定量法は非常に好結果を与えることが確められた。

\title{
実験及び結 果
}

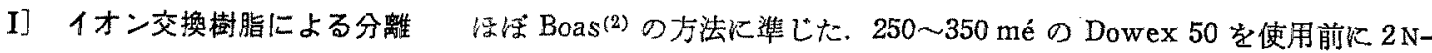
$\mathrm{NaOH}$ 水溶液で数回浸漬処理した後, 水洗, 次いで $2 \mathrm{~N}-\mathrm{HCl}$ 水溶液で浸渍処理し, 塩素イオンの消失するまで

* Chemical Studies on the Reaction Products of Glucose and Ammonia. Part II. Fractional

Determination of Glucose, Glucosylamine and Ammonia.

By Masahiko KōMoTo (The Hyogo University of Agriculture) 


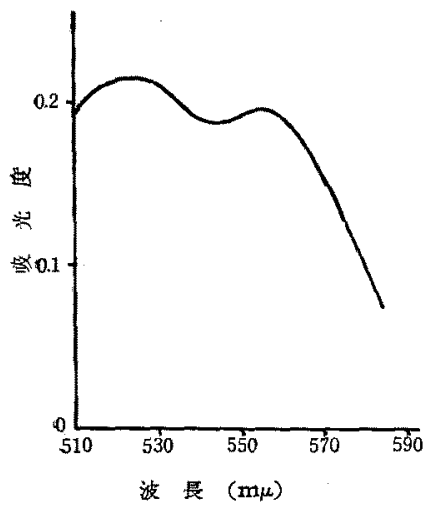

第 1 图グルコシルアミンの

Elson-Morgan 反応

(グルスシルアミン $1.5 \mathrm{mg} / \mathrm{ml})$

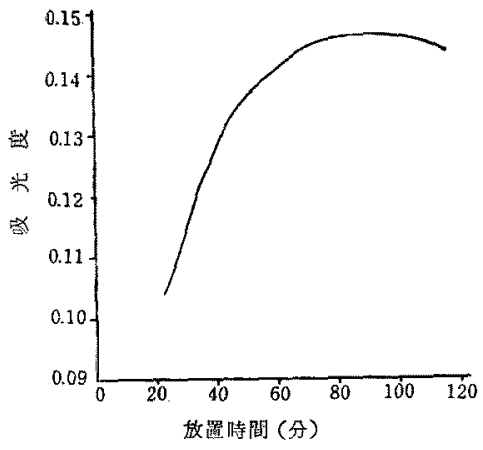

第2図 ダルコシルアミンの

Elson-Morgan 反応啳の

故管時間と吸光度 (ダルコンルマミン $1.3 \mathrm{mg} / \mathrm{ml}$ )

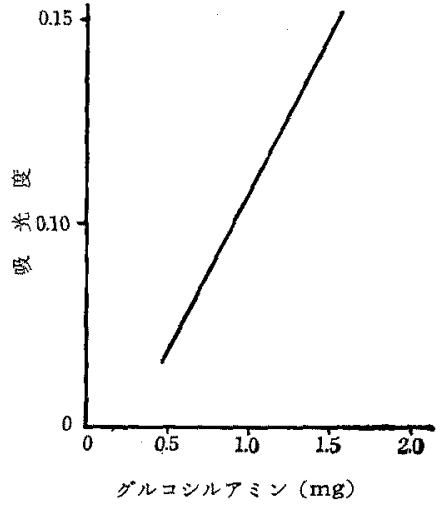

第3図 Elson-Morgan 法における グルコシルフミンの検量線

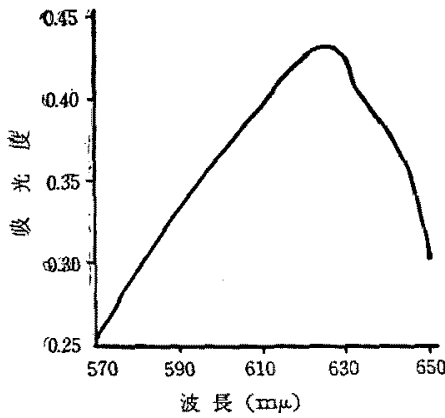

第 4 困 ク゚ルコシルアミンのアンス ロン法淿よる吸光曲線

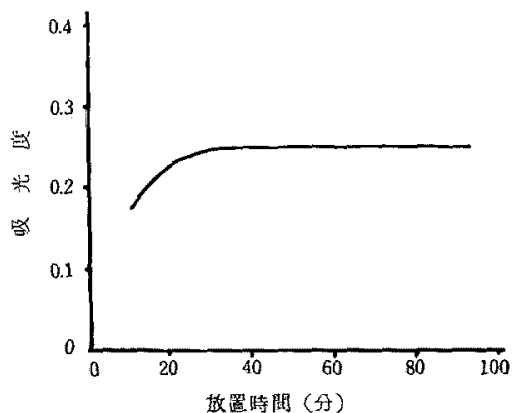

第 5 因 グルコシルアミンのアンス ロン法後の放置時間と吸光度

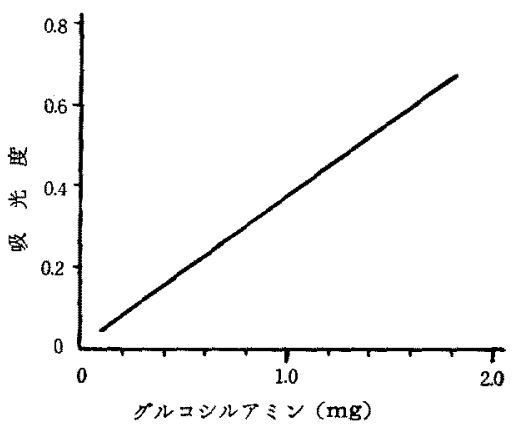

第 6 図 アンスロン法に括けるグル コシルアミンの㭘量線
第 1 表 Elson-Morgan 法によるグルコシルアミンの

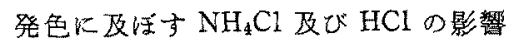

$$
\text { 試 }
$$$$
\text { 料 }
$$

グルコシルアミン $1 \mathrm{mg}$

グルコシルアミン $1 \mathrm{mg}+\mathrm{NH}_{4} \mathrm{Cl} 1.7 \mathrm{mg}$

ダルコシルアミン $\mathrm{Img}+\mathrm{NH}_{4} \mathrm{Cl} 0.85 \mathrm{mg}$

グルコシルフミン $1 \mathrm{mg}+\mathrm{NH}_{4} \mathrm{Cl} 0.51 \mathrm{mg}$

$\mathrm{NH}_{4} \mathrm{Cl} 1.7 \mathrm{mg}$

$\mathrm{NH}_{4} \mathrm{Cl} \quad 0.85 \mathrm{mg}$

グルコシルマミン $1 \mathrm{mg}+\mathrm{HCl} 1 \mathrm{mg}$

ク゚ルコシルフミン $1 \mathrm{mg}+\mathrm{HCl} 2 \mathrm{mg}$

$\mathrm{HCl} 1.4 \mathrm{mg}$

発色時门 吸光畏

0.110

0.157

0.134

0.125

0.044

0.020

0.108

0.112

0.000
第 2 麦 アンスロン法によるグルコシルアミンの発色 级ばす $\mathrm{NH}_{4} \mathrm{Cl}$ 及び $\mathrm{HCl}$ の影響 試 料

グルコシルアミン $1 \mathrm{mg}$

発色時の
グルコシルアミン $1 \mathrm{mg}+\mathrm{NH}_{4} \mathrm{Cl} 1 \mathrm{mg}$

$\mathrm{NH}_{4} \mathrm{Cl} 11 \mathrm{mg}$

ダルコシルアミン $1 \mathrm{mg}+\mathrm{HCl} 14 \mathrm{mg}$

グルコシルアミン $1 \mathrm{mg}+\mathrm{HCl} 7 \mathrm{mg}$

グルコシルアミン $1 \mathrm{mg}+\mathrm{HCl} 1.4 \mathrm{mg}$

ク゚ルコシルアミン $1 \mathrm{mg}+\mathrm{HCl} 0.014 \mathrm{mg}$

$\mathrm{HCl} 36.5 \mathrm{mg}$

$\mathrm{HCl} 14 \mathrm{mg}$
吸光度

0.380

0.377

0.000

0.400

0.390

0,381

0.378

0.015

0.005

我洗し乾懆する，樹脂用カラムム内径 $1 \mathrm{~cm}$, 高さ $30 \mathrm{~cm}$ のガラス管の先端を細くしたものを用いた．樹脂用カ

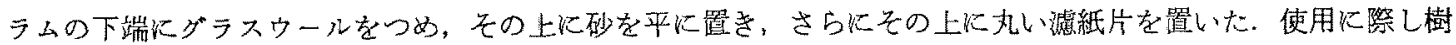

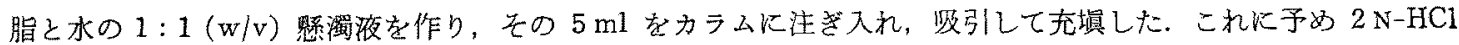

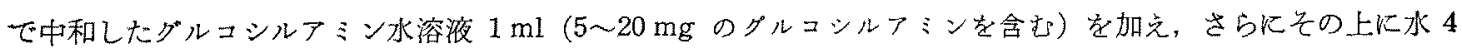
$\mathrm{ml}$ を加えた。流下速度は $5 \mathrm{ml} / 45$ 分を維持するよ弓調節した，通過液及び水に上る洗熦後，計 $15 \mathrm{ml}$ を合して グルコースの定量に供した。 ついで $2 \mathrm{~N}-\mathrm{HCl}$ を加えてグルニシルアミン及びアンモニアを溶出し, その溶出液 $15 \mathrm{ml}$ についてグルコシルアミン及びアンモニアの定量を行った，試料溶液が着色している場合，着色物䓄梅は樹 脂に吸着されたままで $2 \mathrm{~N}-\mathrm{HCl}$ により溶出されない。

II] グルコシルアミン定量法の檢討 


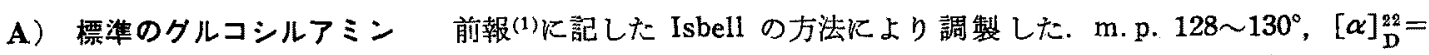
$+20.0^{\circ}\left(c=7, \mathrm{H}_{2} \mathrm{O}\right)$.

B） 測 定 法

a. Elson-Morgan 法：Boas(2) の記載している方法に準じ, Elson-Morgan 法によりグルンシルアミンを

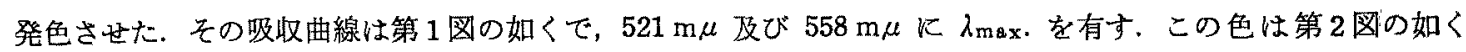
反応後 70〜95 分で最高值に達し，その間は安定である。検量線は第 3 図の如く，グルニシルアミン舅 $0.5 〜 1.5$ $\mathrm{mg}$ の範囲内で直線性がある，従って被験溶液中のグルコシルアミン濃度をこの範囲内に調整し，反応後 70〜 95 分の間に $521 \mathrm{~m} \mu$ に括ける吸光度を測定すれば満足な結果が得られる. しかし上記交換樹脂法により，G-A 反応液中のグルコシルアミンを定量する場合は，共存している塩化アンモンの影響を考慮に入れねばならぬ Elson-Morgan 法によりグルコシルアミンを定量する場合の塩化アンモンの影響は第 1 表の如くで，塩化アンモ ンの存在はグルコシルアミンの定量值を突祭より高めに与える。よって G-A 反応液から交換樹脂により分離し たグルコシルアミンの定量法として、Elson-Morgan 法は不適当である.

b. アンスロン法(3)： あらかじめ水水中で共栓付試験管を泠却し，これに冷却して牤いたアンスロン試薬

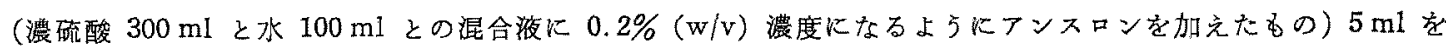


騰水浴中で 10 分加蓺後比色を行5，反応液の吸収曲線安定度及び検量線はそれぞれ第 4，5 及び6图に示す。

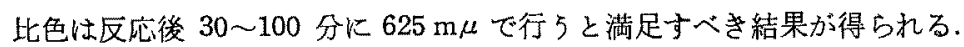

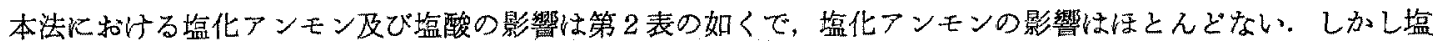
酸は，その量が多くなるとやや（十）の愦差を与える傾向がある．樹脂からの溶出液中に合まれる遊離の塩酸濃 度は約 $1.5 \mathrm{~N}$ であるから，本法を溶出液中のグルコシルアミンの定量に用いるときには，此色の対照液として水 $0.5 \mathrm{ml}$ を用いる代りに，1.5 N-HCl を $0.5 \mathrm{ml}$ 加兑て同様の発色操作を行ったものを使用する.

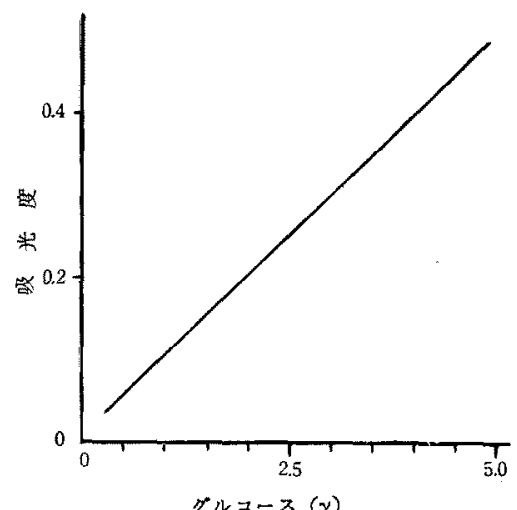

第 7图アンンスロン法におけるグル コースの検量線

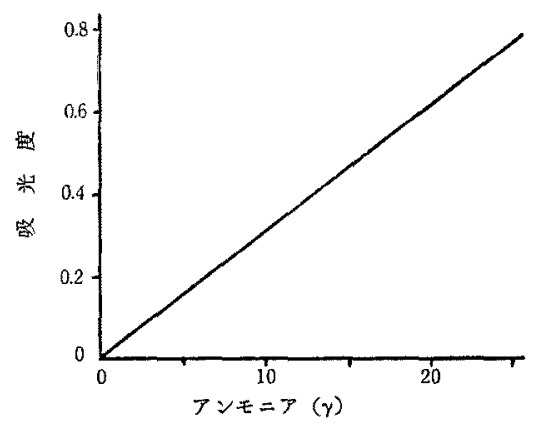

第8图イントフェノール法における アンモニアの㭘量線

III］グルコースの定量法グルコースは前記の交換樹脂による 分離操作では吸着さ扎ずに通過するから，通過液と洗淮液とを合した すのをグルニース量に応じ適当に稀釈し，アンスロン法により測定し た，被験溶液中には塩酸はほとんど含来れず，此色の対照液として水 を用い，满足すべき結果が得られた，検量線は第 7 図の如くで岁る。

IV] アンモニアの定量 樹脂からの溶出液 $0.5 \mathrm{ml}$ を共栓付き 試験管にとり,インドフェノール法によりアンモニアの定量を行った。

第3 表 本分別定量法による各成分の回収率

\begin{tabular}{|c|c|c|c|}
\hline 試 & 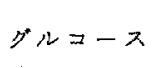 & $\begin{array}{l}\text { グルコシル } \\
\text { フミン }\end{array}$ & フンE $=$ T \\
\hline グルコシルアミン $0.455 \mathrm{mg}$ & 一 & $\begin{array}{l}0.460 \mathrm{mg} \\
(101.1 \%)\end{array}$ & - \\
\hline グルコシルフミン $0.910 \mathrm{mg}$ & - & $\begin{array}{l}0.880 \mathrm{mg} \\
(96.7 \%)\end{array}$ & - \\
\hline $\mathrm{NH}_{4} \mathrm{Cl}, \mathrm{NH}_{3}$ として $0.017 \mathrm{mg}$ & - & - & $\begin{array}{l}0.0166 \mathrm{mg} \\
(97.0 \%)\end{array}$ \\
\hline $\mathrm{NH}_{4} \mathrm{Cl}, \mathrm{NH}_{3}$ として $0.033 \mathrm{mg}$ & - & - & $\begin{array}{l}0.033 \mathrm{mg} \\
(100.0 \%)\end{array}$ \\
\hline $\mathrm{NH}_{4} \mathrm{Cl}, \mathrm{NH}_{3}$ として $0.067 \mathrm{mg}$ & - & 一 & $\begin{array}{r}0.0665 \mathrm{mg} \\
(99.3 \%)\end{array}$ \\
\hline $\begin{array}{l}\text { グルコース } 5.5 \mathrm{mg} \\
\text { 十グルコシルアミン } 0.91 \mathrm{mg}\end{array}$ & $\begin{array}{l}5.5 \mathrm{mg} \\
(100.0 \%)\end{array}$ & $\begin{array}{l}0.94 \mathrm{mg} \\
(103.3 \%)\end{array}$ & - \\
\hline 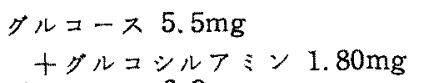 & $\begin{array}{c}5.7 \mathrm{mg} \\
(103.6 \%)\end{array}$ & $\begin{array}{l}1.80 \mathrm{mg} \\
(98.9 \%)\end{array}$ & 一 \\
\hline $\begin{array}{l}\text { グルコース } 6.3 \mathrm{mg} \\
+ \text { オルコシルフシン } 15.0 \mathrm{mg} \\
+\mathrm{NH}_{4} \mathrm{Cl}, \mathrm{NH}_{3} \text { として } 2.1 \mathrm{mg}\end{array}$ & $\begin{array}{l}6.6 \mathrm{mg} \\
(104.8 \%)\end{array}$ & $\begin{array}{l}15.3 \mathrm{mg} \\
(102.0 \%)\end{array}$ & $\begin{array}{l}2.064 \mathrm{mg} \\
(98.3 \%)\end{array}$ \\
\hline $\begin{array}{l}\text { グルニース } 3.15 \mathrm{mg} \\
+ \text { グルシンアミン } 7.5 \mathrm{mg} \\
+\mathrm{NH}_{4} \mathrm{Cl}, \mathrm{NH}_{3} \text { ¿して } 1.05 \mathrm{mg}\end{array}$ & $\begin{array}{l}3.105 \mathrm{mg} \\
(98.6 \%)\end{array}$ & $(9.2 \mathrm{mg})$ & $\begin{array}{l}1.032 \mathrm{mg} \\
(98.3 \%)\end{array}$ \\
\hline 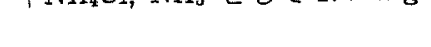 & c & 内は回败就 & \\
\hline
\end{tabular}


塩酸及びグルコシルアミンの影響はなく，満足すべき結果を与えた．検量線は第 8 图の如くである.

V] 本法によるグルコシルアミン, グルコース及びアンモニアの回収率 第 3 表に示す如く既知量のグルコシ ルアミン,グルコースをたは塩化アンモンを含む水溶液, 或いはそれらの二者または三者の混合水溶液をそれそ れI]の方法に従い交換樹脂により分離した後, グルコース及びグルコシルアミンはアンスロン法によりアンモ ニアはインドフェノール法により比色定量した. 第3表に明らかな如く, それぞれの回取率は極めて高い上っ て本法がグルコース，グルコシルアミン及びアンモニアの分別定量法として採用できることが確められた。

\section{考察}

（a）グルコシルアミンは水溶液中では，かなり不安定な物質である.よって約 4.5 時間にわたる分離操作中 に分解することが榡念された，乙かし第 3 表に示した如く，分離及び測定に必要とされる時間内では倹知し得る ていどの分解の起らねことが判明した.

（b） アンスロン法によるグルコシルアミン及びグルュースの分子吸光保数をそれぞれの検量線の直線部分か ら算出すると、グルコシルアミンの 67 に対しグルコースは 1742 である.すなわちグルコースの発色率を 100 とすれば,グルコシルアミンのそれは約 4 でする. 従ってアンスロン法によりグルコースを定量する場合は, 少 量のグルコシルアミンが存在してもたいした影響はないが, グルコシルアミンを定量する場合は，微量のグルコ

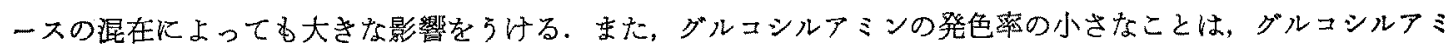
ンの濃度变化伴う吸光度の変化の小さなことを示するので, 微小の差を検知しにくい.

（c）本法では交換樹脂通過液中のアンスロン試薬陽性の物質は，すべてグルコースとみなして定量した. しかし G-A 反応液中にはフラクトース及びマンノースがそれぞれ少量生成する。これらの糖のアンスロン法に よる発色率はダルコースと若干異っているから，わずかの䛊差はま妨れ゙れい、また，同じく G-A 反応液に生 成するジグルコシルアミンの発色率は，グルコースを100とすると23 である. ジグルコシルアミンは交换樹脂 により吸着されず，グルコ一スと共炕通過液中海行する，その発色率は小さく，その生成量る小さいと考えら れるから，グルコースの定量值には余り影響を及ばさないと考えられるが，この場合ダルコースの定量值性近似 的なるのになることは避けられない。

要 約

グルコース，グルコシルアミン及びアンモニアを分別定量する方法を倹討したが、ほぼ满足すべき結果を得た。 すなわち既知量の三者の混合溶液をBoas の方法に準し，Dowex 50 Kよりグルコースと，グルコシルアミン及 びアンモニアを含む二区分に分別した，グルコース及びグルコシルアミンをアンスロン法により，アンモニアを インドフェアール法炕より定量して各隹ぼ 100\%に近い回収率を得た。

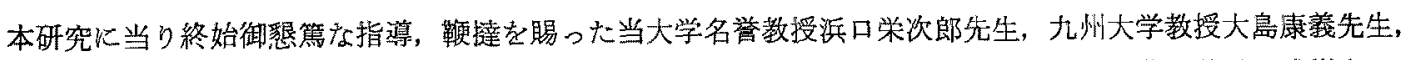
名古屋大学教授目村悌一先生に深甚の謝意を䘚す，また研究遂行中御授助を受けた当大学藤井聰氏に感謝する.

(1) 河本正应：本誌，36，305 (1962).

(2) N. F. Boas ; J. Biol. Chem., 204, 553 (1953).

（3）生化学額域に和け当光笔此色法, 各諭 2 ,

$$
\text { p. } 36 \text { (1958). }
$$

(4) 同上, 各墖 1, p. 42 (1958).

(5) 同上, 各諭 2, p. 46 (1958). 